\title{
Pemodelan Reservoir Panasbumi Menggunakan Data Magnetik di Desa Toro Kecamatan Kulawi
}

\section{Geothermal Reservoir modeling using Magnetic Data in Toro Village Kulawi Districts}

\author{
Chris Indra Cahya Baligau, Sandra Kasim, Rustan Efendi*)
}

Lab. Fisika Bumi Jurusan Fisika, Fakultas Matematika dan Ilmu Pengetahuan Alam, Universitas Tadulako

\begin{abstract}
Magnetic research at the site of the geothermal manifestations Toro Rural District of Kulawi Sigi has been conducted. The aim of research is to model the structure of the geothermal reservoir rock composer and estimate the depth of the geothermal reservoir using magnetic data obtained in the field. The obtained magnetic data subsequently processed to the stages of doing some correction such as a IGRF correction and daily variation correction in order to obtain the total magnetic field anomaly data. Forward modeling inverse modeling is used to determine the geothermal reservoir rocks layers and depth. Modeling results showed that the reservoir rock constituent is consisted non-magnetic minerals with susceptibility values are: -0.00030125 SI,-0.003413 SI, -0.0084446 SI, -0.05824451 SI and -0.066777 SI. Geothermal reservoir is laid at depth of 2000-3000 m below surface.
\end{abstract}

Keywords: Susceptibility, Reservoir, Geothermal.

\begin{abstract}
ABSTRAK
Penelitian magnetik telah dilakukan di lokasi manifestasi panasbumi Desa Toro Kecamatan Kulawi Kabupaten Sigi. Tujuan penelitian untuk memodelkan struktur batuan penyusun reservoir panasbumi dan mengestimasi kedalaman reservoir panasbumi. menggunakan data magnetik yang diperoleh di lapangan. Data magnetik yang diperoleh selanjutnya diolah dengan tahapan melakukan beberapa koreksi yaitu koreksi IGRF dan koreksi vairiasi harian guna memperoleh data anomali medan magnet total. Pemodelan kedepan (Forward Modeling) dan Pemodelan kebelakang (Inverse Modeling) digunakan untuk mengetahui batuan penyusun reservoir panasbumi dan kedalamannya. Hasil pemodelan diperoleh bahwa batuan penyusun reservoir berupa batuan yang tersusun atas mineral non magnetik dengan nilai suseptibilitas yaitu: -0,00030125 SI, -0,003413 SI, 0,0084446, SI, -0,05824451 SI dan -0,066777 SI. Reservoir panasbumi berada pada kedalaman 2000-3000 $\mathrm{m}$ di bawah permukaan.
\end{abstract}

Kata Kunci : Suseptibiltas, Reservoir, Panasbumi.

Coresponding Author : rst_efendi@yahoo.com (ph/fax:081322963707) 


\section{LATAR BELAKANG}

Seiring dengan bertambahnya jumlah populasi manusia, maka kebutuhan mengenai sumber energi akan semakin bertambah pula guna memenuhi kebutuhan sehari-hari. Saat ini ada begitu banyak teknologi yang digunakan untuk memenuhi kebutuhan hidup manusia yang memanfaatkan sumber energi yang sulit terbarukan contohnya pembangkit listrik tenaga uap yang menggunakan batu bara sebagai bahan bakarnya dan pembangkit listrik tenaga diesel yang menggunakan solar yang berasal dari minyak bumi. Jika eksploitasi besar-besaran terhadap sumber energi yang sulit terbarukan itu terus dilakukan, maka bisa dipastikan suatu saat kita akan mengalami krisis energi yang parah karena mengingat kebutuhan akan sumber energi yang terus meningkat tetapi tidak disesuaikan dengan jumlah cadangan sumber energi yang ada. Oleh karena itu perlunya mencari sumber energi alternatif terbarukan yang menjadi potensi daerah. Salah satu sumber energi tersebut adalah panasbumi atau geothermal (Daryanto, 2007). Pemodelan reservoir panasbumi ini sangat penting dilakukan guna menjawab krisis energi yang terjadi secara global pada saat ini (Saptadji, 2009). Adapun tujuan yang hendak dicapai dari penelitian ini adalah memodelkan struktur lapisan batuan penyusun reservoir panasbumi Desa Toro
Kecamatan Kulawi dan mengestimasi kedalaman reservoir Panasbumi Desa Toro Kecamatan Kulawi melalui pemodelan.

\section{BAHAN DAN METODE}

Bahan yang digunakan dalam penelitian adalah Peta Geologi Lembar Poso dan Peta RBI lembar Lawua.

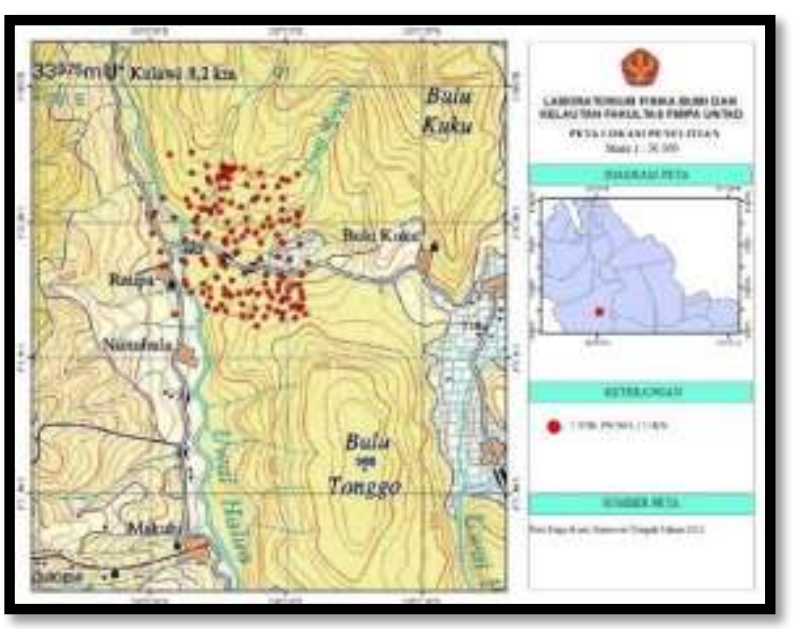

Gambar 1 Peta Lokasi Penelitian. Lokasi pengambilan data ditunjukkan dengan titik berwarna merah.

Penelitian dengan menggunakan metode geomagnet dilakukan di Dusun Raupa, Desa Toro, Kecamatan Kulawi, Kabupaten Sigi, Provinsi Sulawesi Tengah. Dusun Raupa berada pada 1030'33.6" LS dan $120^{\circ} 0^{\prime} 46.6^{\prime \prime}$ BT dapat dilihat peta rupa bumi pada Gambar 1 dan peta geologi pada Gambar 2. Secara umum metode yang digunakan dalam penelitian ini adalah pengukuran medan magnetik bumi atau geomagnet. Data intensitas medan magnet merupakan data terukur yang diperoleh dari proses akuisisi data selanjutnya dilakukan pengolahan data, mulai dari beberapa 
koreksi diantarranya koreksi IGRF dan koreksi variasi harian sehingga didapatkan data medan magnet total. Data medan total dan data ketinggian lokasi penelitian digunakan sebagai data input pada pemodelan forward modelling dan inverse modeling. Selanjutnya dilakukan proses analisis dan interpretasi model yang diperoleh.

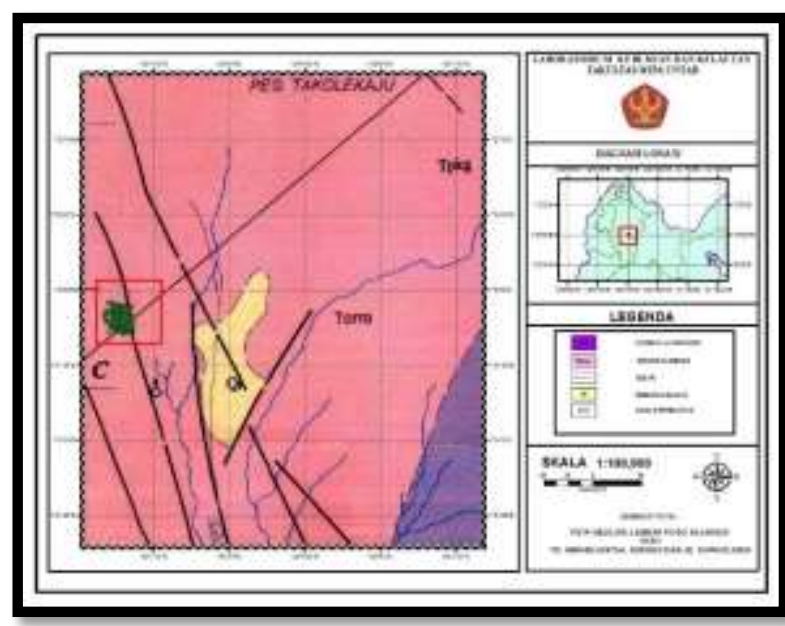

Gambar 2. Peta Geologi Lokasi Penelitian. Daerah berwarna merah muda yang artinya formasi Granit Kambuno yang tersusun atas granit dan granidiorit. Granit berwarna putih berbintik hitam, berbutir sedang sampai kasar, terdiri atas granit biotit, granit hornblende biotit, mikroleukogranit, dan mikrogranit horenblenda-biotit. Granodiorit mengandung mineral mafik horenblenda. (Simanjuntak, 1977).

\section{HASIL DAN PEMBAHASAN}

Kondisi bawah permukaan atau batuan penyusun reservoir panasbumi menggunakan teknik pemodelan kedepan (forward modeling) dan pemodelan kebelakang (inverse modeling). Pemodelan kedepan dilakukan dengan cara membangun model lapisan bawah permukaan menggunakan data anomali magnetik total di sepanjang lintasan titik koordinat tertentu pada lokasi penelitian. Adapun lintasan-lintasannya sebagai berikut: Lintasan AA' berada pada 168136 LS 9832830 BT sampai 167063,7 LS 9833346 BT, Lintasan BB' berada pada 167317 LS 9833451 BT sampai 167462.4 LS 9832352 BT, Lintasan CC' berada pada 167519.1 LS 9833461 BT sampai 167582 LS 9832348 BT, Lintasan DD’ berada pada 167820.4 LS 9833454 BT sampai 167880.7 LS 9832352 BT dan Lintasan EE' berada pada 167068.8 LS 9833256 BT sampai 168153.7 LS 9833344 BT. Lintasan-lintasan tersebut dapat dilihat pada Gambar 3.

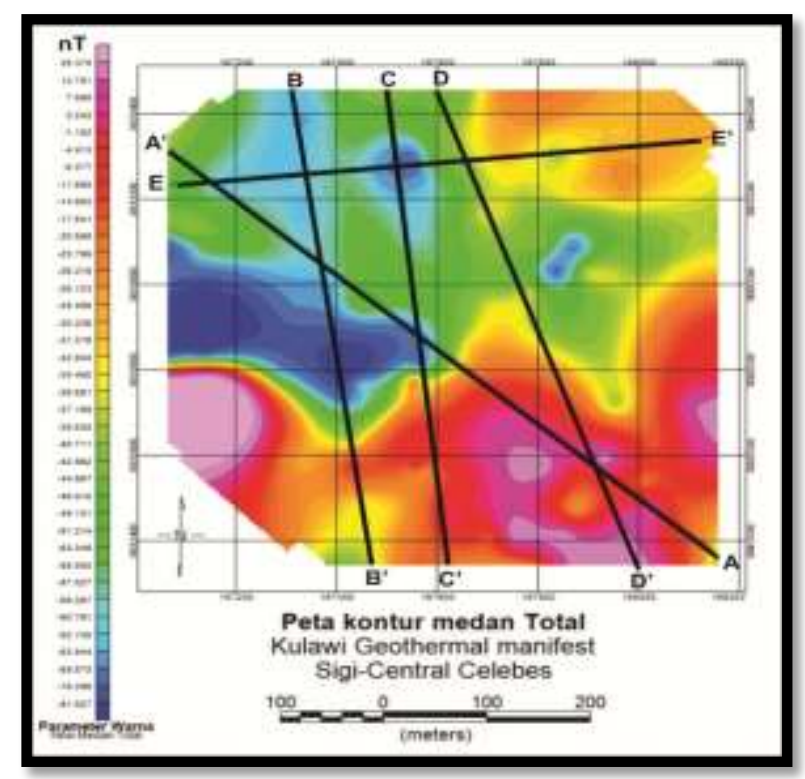

Gambar 3. Peta kontur medan total dengan penampang hasil slice. Peta diatas merupakan peta kontur medan magnet total dengan garis penampang lokasi penelitian yang hendak dimodelkan bawah permukaannya.

Pemodelan Reservoir Panasbumi Menggunakan Data Magnetik di Desa Toro 
Untuk mengetahui struktur lapisan batuan penyusun dan kedalaman reservoir Panasbumi Kulawi, dibutuhkan teknik pemodelan kedepan dan pemodelan kebelakang. Metode tersebut merupakan suatu metode matematika yang digunakan untuk mengolah data menjadi suatu bentuk model struktur lapisan batuan lokasi penelitian. terlihat bahwa model bawah permukaan lokasi penelitian tersusun dari beberapa jenis batuan dan mineral penyusunnya. Lintasan AA' pada Gambar 4 menggambarkan bahwa model bawah permukaan tersusun atas beberapa jenis batuan dan mineral diantaranya batuan beku yang berupa granit, mineral penyusunnya berupa mineral non magnetik. Batuan sedimen dan batuan beku serta mineral-mineral penyusun bawah permukaan lokasi penelitian berada apada kedalaman 0 m- $1000 \mathrm{~m}$ di bawah permukaan. Batuan yang berupa penyusun dari reservoir panasbumi, ada pada kedalaman > $2000 \mathrm{~m}$ di bawah permukaan serta batuan penyusunnya berupa mineral non magnetik dengan nilai susuptibilitas 0,00030125 SI. Nilai suseptibilitas negatif menandakan bahwa batuan yang ada di lokasi tersebut kehilangan mineral magnetiknya sebagai akibat dari pemanasan dari sumber panas yang ada di bawah permukaan. Lintasan BB' pada Gambar 5 menunjukkan batuan penyusun bawah permukaan lokasi penelitian adalah sedimen yang berupa red sediment, batuan beku yang berupa granit, dan iron sulfides berupa pirit. Batuan penyusun didominasi oleh batuan beku granit. Batuan sedimen dan batuan beku berada pada kedalaman 0 m - 1000 m di bawah permukaan. Pada line_2 batuan penyusun reservoir panasbumi berupa batuan dengan mineral non magnetik sebagai penyusunnya dengan nilai suseptibiltas $-0,003413$ SI. Kedalaman reservoir ada pada > $2000 \mathrm{~m}$ di bawah permukaan.

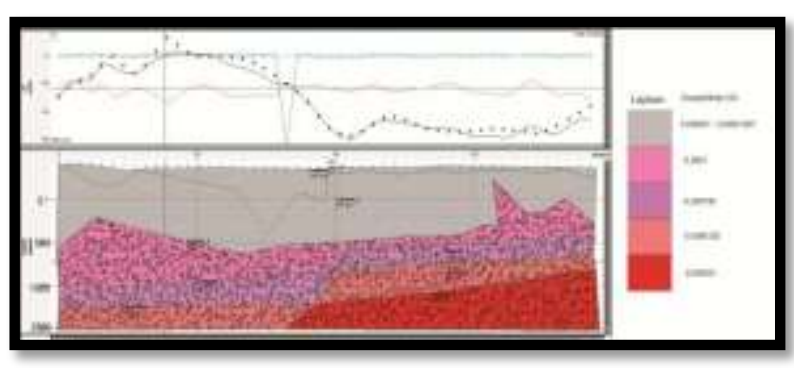

Gambar 4. Model bawah permukaan pada lintasan AA'. Batuan penyusun reservoir panasbumi adalah mineral non magnetik dan berada pada kedalaman 2000-2600 m di bawah permukaan.

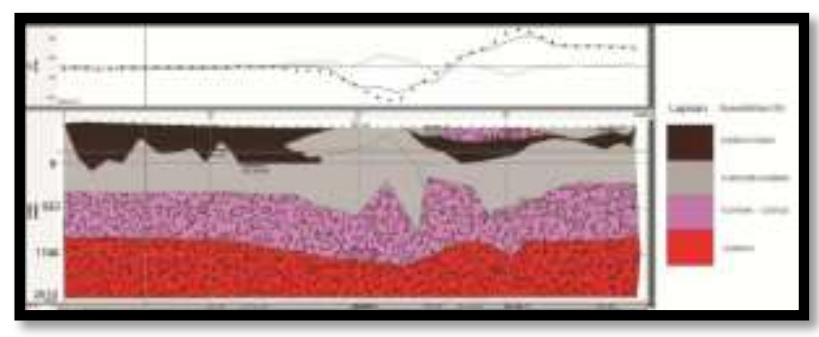

Gambar 5. Model bawah permukaan pada lintasan BB'. Batuan penyusun dan kedalaman reservoir panasbumi pada lintasan ini adalah berturut-turut mineral non magnetik dan 2000-2600 m di bawah permukaan. 
Lintasan CC' pada Gambar 6 menunjukan bahwa di bawah permukaan lokasi penelitian terusun atas batuan sedimen berupa clay (lempung), batuan beku berupa granit dan tersusun atas mineral magnetik biotites. Dimana granit dan mineral magnetik biotites sebagai batuan penyusun yang mendominasi. Batuan Sedimen dan batuan beku berada pada kedalaman $<1000$ $m$ di bawah permukaan. batuan yang berada pada kedalaman $>1000 \mathrm{~m}->2000$ $\mathrm{M}$ di bawah permukaan merupakan batuan dengan mineral penyusunnya berupa mineral non magnetik dengan nilai suseptibiltas -0,004446 SI. Batuan tersebut berupa batuan penyusun reservoir panasbumi, hal itu ditunjukkan dengan nilai suseptibilitas batuan yang bernilai minus atau batuan dengan sifat diamagnetik. Lintasan DD' pada Gambar 7 memperlihatkan struktur bawah permukaan lokasi penelitian yang tersusun dari beberapa jenis batuan, diantaranya: batuan beku yang berupa granit, basalt dan rhyolite, batuan sedimen berupa clay (lempung), dan mineral magnetik biotites Batuan lain adalah batuan dengan mineral non magnetik yang ada pada kedalaman $2000 \mathrm{~m}$ - $3000 \mathrm{~m}$ di bawah permukaan. Batuan tersebut berupa batuan penyusun reservoir panasbumi yang ada pada lokasi penelitian. Nilai suseptibilitasnya yaitu 0,05824151 SI. Lintasan EE' pada Gambar 8 terlihat bahwa batuan penyusun bawah permukaan terdiri atas batuan beku berupa granit, basalt dan rhyolite dan batuan sedimen berupa red sediment. Batuan yang dengan mineral penyusunnya adalah mineral non magnetik merupakan batuan penyusun reservoir panasbumi yang ada pada kedalaman 2000 m -3000 m di bawah permukaan. nilai susuptibilitas batuan penyusun reservoir panas bumi yaitu 0,066777 SI.

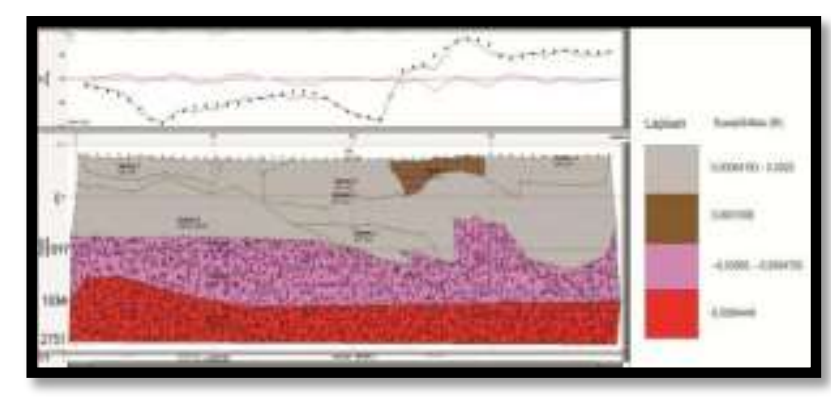

Gambar 6. Model bawah permukaan pada lintasan CC'. Batuan penyusun reservoir panasbumi adalah mineral non magnetik yang berada pada kedalaman 2000-2700 m di bawah permukaan.

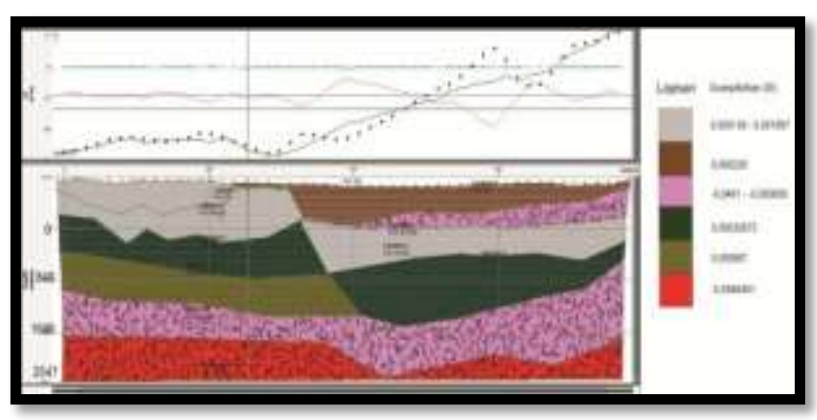

Gambar 7. Model bawah permukaan pada lintasan DD'. Kedalaman reservoir adalah 2000-2500 m di bawah permukaan dengan penyusunnya reservoir adalah mineral non magnetik. 


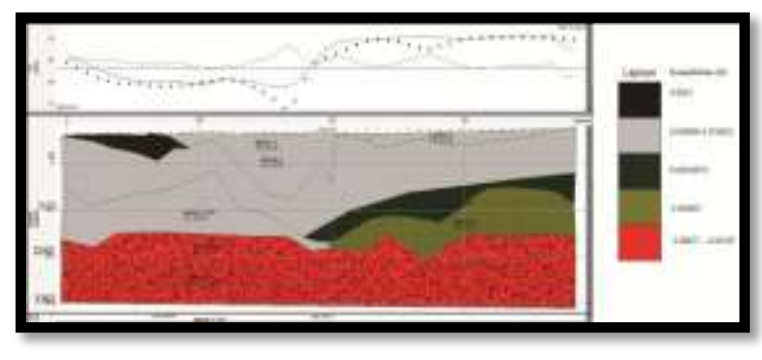

Gambar 8. Model bawah permukaan pada lintasan EE'. Batuan penyusunnya panasbumi adalah dengan mineral non magnetik yang berada pada kedalaman 2000-3200 m di bawah permukaan.

Dari ke 5 model yang telah diperoleh, menggambarkan bahwa batuan penyusun bawah permukaan lokasi penelitian adalah batuan beku berupa granit, batuan sedimen berupa clay (lempung), dan mineral magnetik biotites. Hal tersebut telah sesuai dengan literatur yang ada (Simanjuntak, 1977), dimana berdasarkan peta geologi bahwa kondisi geologi lokasi penelitian tersusun atas batuan granit berbintik hitam dan granit dengan mineral penyusun berupa mineral magnetik biotites dapat dilihat pada Gambar 2. Reservoir panasbumi tersusun atas batuan dengan mineral non magnetik dengan kedalaman mencapai $2.000 \mathrm{~m} \mathrm{-}$ $3.000 \mathrm{~m}$ di bawah permukaan lokasi penelitian. Mineral non magnetik memiliki nilai suseptibilitas yang sangat kecil atau di bawah nilai 0 . Hal itu dikarenakan batuan mengalami pemanasan dari sumber panasbumi dan sebagai akibatnya batuan kehilangan sifat magnetiknya (Telford, 1976). Oleh karena itu dapat diketahui reservoir panasbumi Kulawi yang ada di Dusun Raupa Desa Toro.

\section{DAFTAR PUSTAKA}

Daryanto. (2007). ENERGI, Pustaka Widyatama, Yogyakarta.

Saptadji Nenny Miryani. (2009). Karekterisasi Reservoir Panasbumi, Institut Teknologi Bandung, Bandung.

Simanjuntak T.O, Surono dan Supandjonu, J.B. (1977). Peta Geologi Lembar Poso, Sulawesi. .

Telford W.M, Geldart L.P dan Sheriff R.E, Keys DA. (1976). Applied Geophysics, Second Edition, Cambridge University Press : New York. 